\title{
The Role of Water Law in the Sustainable Development in Indonesia
}

\author{
Pulung Widhi Hari Hananto \\ Faculty of Law, Universitas Diponegoro \\ Prof. Soedarto, SH, Street, Tembalang, Semarang \\ hananto.pulung@undip.ac.id
}

\begin{abstract}
Water always have been a part of human's life and it is very essential for human's need. In recent decades, the polemic of water has increased and made of lot victim with diverse background. The major issue there's no effective water management and water security (water protection). Because of that, the lack of access to clean water always happen and the worst, also gives serious impact in human right aspect and big obstacle for sustainable development. That's why it needs a role of water law to resolve this problem. In this paper, the writer would like to elaborate and harmonize the importance role of water law in order to guarantee the sustainable development.
\end{abstract}

Key words: water law, water security, water management

\section{A. Introduction}

UN estimates and indicate that nearly 1.5 million children underage 5 die every year from water while some 1 billion people lack access to clean drinking water and a further 2.6 billion do not have basic sanitation facilities. ${ }^{1}$ This clearly evidence that water and sanitation are essential for life, health, dignity, empowerment and prosperity. The right to water and sanitation entails that every country must priorities ensuring access to minimum essential supplies to safe water services and basic sanitation for all people and use available resources accordingly. Today, the water sector is characterized by a very complex and problematical situation. Operation of water services, legal framework (water security) and the condition of water are key issues for this problem, not only in regional area but most of countries. The right of every human being to safe drinking water and basic sanitation should be recognized and realized. This situation is need more concern for international community alongside with this issue.

\footnotetext{
${ }^{1}$ United Nations Departements of Economic and social Affairs, Population Division, 2004.
} 
In order to respect with this situation, the International community recognizes the need to improve the management of its global water resources, and the UN "Water for life Decade", announced by UN Secretary-General Kofi Annan in march 2005, demonstrates, in many ways, the increased focus on issues related to water security and resources. The notion of "water security" is not a new one, but is being reconsidered in current global discourse - a reinvigorated concept inviting closer study. In the United Nations Environment Programmer's (UNEP) report on environment and security, "Understanding Environment, Conflict and Cooperation', UNEP executive director Klaus Toepfer states: ${ }^{2}$

Maintaining environmental quality and improving degraded environments are preconditions for achieving sustainable development and meeting the Millennium Development Goals. They are also crucially important for enhancing human well-being, including security. The United Nations Environment Programmed has therefore been interested in promoting understanding of the relationship between environment and peace.

Based on the statement above, we can say that the problem related to the management of water supply and distribution are exist. This is partly due to extensive industrialization, increased population density and present high rate of urbanization. For every country, water is crucial resource with great implications. This because the present freshwater situation in the world is not totally encouraging. Globally, the middle east and part of Africa are the countries with the most limited water resources. Nowhere more that in Africa and Middle East is water likely to become critical issues, which is a great limiting input to food security, economic and social development of the estimated 800 million who live on the Africa continent, more than 300 million live in water-scare environment. ${ }^{3}$

The lack of access water to clean water is a serious health concern. Report have revealed that about 2.3 billion people suffer from disease that are linked to dirty water and that water related disease are growing human tragedy, leading to death of 5 million people yearly. This number is said to be 10 times the number of people killed in wars. Also, water that is contaminated with nutrients, nitrate presence in water is known to cause digestive tract ulcers

\footnotetext{
${ }^{2}$ UNEP (2004) Understanding Environemne, Conflict and Cooperation, 6 October ; avalaible at www.unep.org

${ }^{3}$ Abubakar, MAK., 2006. Water Supply and sanitation sector reform initiatives in Nigeria Proceeding of the 29th WEDC Conference, Symposium on a Key National Issue, Sep 24 Nigeria, pp : 1-16
} 
and in infant leads to restriction of two restriction of the amount of oxygen to the brain, leading to the blue baby syndrome. ${ }^{4}$

\section{B. Result and Discussion}

\section{Current Status in Indonesia}

Concession agreements are an instrument for a country to invite the private sector to invest in managing water resources. The concession agreement option was chosen by the Government, because state ownership of water resources can still be maintained even though the right to manage clean water is transferred to the private sector. The inclusion of private participation in the operation of water resources is an issue that raises pros and cons, even before the Act. No. 7 of 2004 concerning Water Resources (hereinafter referred to as the Water Law) was officially enacted.

The commitment of the privatization of water resources by the Government of the Republic of Indonesia began since the signing of the WATSAL (Water Resource Sector Adjustment) with the World Bank in 1999. The purpose of the contents of the loan agreement worth 300 billion US Dollars aims to carry out reforms in the field of water management. Through a number of policies to strengthen institutions and legal instruments for the management of watershed resources (DAS), water pollution management, and management of water resources and irrigation systems. WATSAL recommendations include three aspects, namely for 1). Artistic planning; 2) Institutional and regulatory systems supported by legislation and support for change (emphasizing decentralization and participation) and 3). financial and opportunity cost problems generated from water and its utilities in a competitive base (as economic goods). ${ }^{5}$

Based on from that agreement, the Government of Indonesia followed up with a reformulation of policies in the field of water resources management. Submission of the draft bill on the field of water resources was forwarded by the government to the Parliament for essential discussion. Together, it was attempted to become a legal basis for the National Law on water resources management. The debate between factions at the Parliaments and

\footnotetext{
${ }^{4}$ ibid

${ }^{5}$ Basah Hernowo, Kebijakan Nasional Pengelolaan Sumber Daya Air, Direktorat Kehutanan dan Konservasi Sumber Daya Air, Kementrian PPN/BAPPENAS yang diakses pada https://www.bappenas.go.id/id/berita-dansiaran-pers/keterpaduan-konservasi-sumber-daya-air-kunci-pembangunan-berkelanjutan/accesed on May 27 2020 at $11.30 \mathrm{PM}$
} 
various political affiliations expressed concern through various mindrheids members. ${ }^{6}$ However, in the end this law was passed by the Indonesian House of Representatives unanimously. The government denies that the existence of the Law on Resources is made as a suggestion to facilitate privatization in water management. This was confirmed by the Minister of Public Works at the time, that the enactment of this regulation was aimed at controlling the behavior of the private sector in managing water resources not for the sake of loosening the privatization of water resources management, the basis for granting privatization concessions for the management of water sources which actually formulated the Water Law. apart from the problem of the clean water crisis in Indonesia

The Challenges of managing water resources has a number of challenges including rigidity of governance from upstream to downstream, weak environmental law enforcement, lack of community participation and so on. These obstacles are rooted in one estuary problem, namely the development of water resources has not become a political issue that is considered a priority scale. The crucial issue that has become a central issue in water privatization is whether the policies contained in the Water Resources Act are in line with the rules in the country's constitution specifically relating to socio-economic rights. With the commodification and privatization of water it has the potential to create a risk of restricting community access to the use of the right to water.

The States are obliged to take legislative and other steps in available resources to ensure the progressive realization of these rights. The constitutionality of privatization depends very much on the context of its role in contributing to the realization of relevant socio-economic rights. Failure to fulfill one of these demands will mean that the policy is unconstitutional, ${ }^{7}$ and that the State violates its constitutional obligations. This point should be an important concern, because the right to water and sanitation is guaranteed in the constitution.

The Decision for privatization is used as an economic development policy option that is commonly used by various stakeholders and financial institutions, and even this agenda has been raised as a major issue that is accommodated in multilateral trade agreements

\footnotetext{
${ }^{6}$ Al'Afghani, Mohamad Mova, Anti privatization Debate, Opaque Rules and Neglected 'Privatized' Water Services Provision: Some Lessons From Indonesia, Background Paper STEPS II Conference, "Liquid Dynamics", organized by the International Development Study (IDS) at the University of Sussex, Sussex, 2223 March 2011, p. 3. p. 3. '[Minderheidsnota is a minor note from the legislator. The content of the minderheidsnota is not binding as law but could be used to supplement interpretation and to provide insight into the history of the formation of a law.]

${ }^{7}$ Koalisi Rakyat Untuk Hak Atas Air / KRUHA, Supranote. 3, p. 13
} 
under the pretext of increasing efficiency in shipping, with the ultimate goal leading to access to basic services. The private sector involved in the service sector sub-sector relating to Socio-Economic Rights must confirm that they do not arbitrarily intervene in the enjoyment of the enjoyment of that right. The possibility of holding such an actor directly responsible by a court of law is under the constitution. ${ }^{8}$

Post - Water Law were officially enacted, a number of new problems arise related to the substance of the norms that are contained therein. One of the issues raised is the emergence of Water Exploitation Right, which is the right to use and commercialize water for commercial purposes that can be given to the private sector (including foreign private) with very flexible conditions. ${ }^{9}$ This provision became the most fundamental main headline of the Act. This point clearly describes the political direction of the national water regulation law which tends to support the privatization of water resources management in Indonesia.

As a result of the policy norms formulated in the Water Law regime, the mandate for management and utilization of water resources by the state as mandated in Article 33 paragraph (3) of the Constitution, namely for the greatest prosperity of the people, actually has the opportunity to reduce the rights of their own people in obtaining and utilizing the resources of their wealth nature belongs to the state. The provisions of water exploitation Right lead to conflicts in its application especially in the implementation of the use of the Water Use Rights by companies with surrounding communities who live close to water sources. Various motives behind the conflict related to the matters described in the sentence above, One of the most common issues on the ground is unilateral control of springs by companies which results in reduced and or loss of community access to water sources in the area concerned.

The lack of control over the opening of access to water management rights to the private sector over the management of water resources as stipulated in the Water Law, indirectly causes conflicts with the undercurrent. Triggers of community conflict with the private sector are described as people's resistance to fighting for their rights to water resources to the unilateral power of a spring water resource company that has eliminated the community's right to access water as a main source of life.

\footnotetext{
${ }^{8}$ Koalisi Rakyat Untuk Hak Atas Air / KRUHA, Supranote. Ibid 13

9 Helmi Kasim dan Titis Anindyajati, "Perspektif Konstitusional Kedudukan Negara dan Swasta dalam Pengelolaan Sumber Daya Air Menurut UUD 1945," Jurnal Konstitusi, Volume 13, Nomor 2, (Juni, 2016), p.. 459
} 
If related to the provisions of Article 33 paragraph (3) of the Constitution of the Republic of Indonesia, it is stated that: " Land and water and all natural resources underneath are under the control of the government and (are to be) exploited as much as possible for the prosperity of the whole nation."

Taking into account these provisions, it can be stated that water is a commodity resulting from natural resources that is protected under the regulation of economic development in the Constitution of the Republic of Indonesia. The Indonesian Constitution qualifies implicitly that water is a Public Goods which belongs to the Joint and has broad influence over all the activities of Indonesian citizens, so that the State must intervene in its control and management to prevent disruption that imposes potential friction in people's lives (equality in accessing and using the commodity fairly). .

The argument in the provision of Article 33 paragraph (3) of the Constitution of The Republic of Indonesia is strengthened by the Constitutional Court of the Republic of Indonesia which interprets the phrase "controlled by the state" as a direct mandate given by the Indonesian people to the Government of the Republic of Indonesia to compile regulations (policies), preservation actions (bestuursdaad) for regulating (regelendaad), management (beheersdaad), and control (toezichthoudensdaad) ${ }^{10}$ for the purpose of overall prosperity of the people.

The phrase "controlled by the state" does not mean that the Government controls physically, but every economic activity related to the exploration of natural resources by individuals or groups in society, especially land and water which has two economic and social functions will be controlled and supervised by the state, with a note that the exploitation activities concerned an obligation is aimed at the interests of the people of Indonesia at large and paying attention to sustainable economic development. This means that the sectors related to natural resources are fully controlled by the State, while the private sector is only permitted to explore the relevant resources through a Cooperation contract between the government and the private sector.

The water law is in principle in line with the provisions of Article 33 of the 1945 Constitution of the Republic of Indonesia As stated in Article 6, par. 1 of the WaterLaw, which reads:

"(1) Water resources must be controlled by the State and used for the greater welfare of the people."

${ }^{10}$ Ahmad Redi. 2014.Hukum Sumber Daya ALam dalam Sektor Kehutanan. Jakarta Timur:Sinar Grafika p.6 
However, in the Water Law there are also inconsistent legal norms that create disharmony with the Constitution, namely Article 45 which provides an opportunity for the private sector to exploit water resources. As stated in paragraph 3 as follows:

3) Utilization of water resources other than those referred to in paragraph (2) may be carried out by individuals, companies, or inter-company cooperation in accordance with exploitation permits from the Government or regional government in accordance with their authority. "

That provisions above are considered to be inconsistent and contrary to the Constitution of The Republic of Indonesia. Values of the use of water resources are only seen and prioritized in the economic function partially. Government policy in establishing private water management does not only focus on the economy, but also considers social approaches and sustainable development that are an integral part of the Political Law of the management and use of the National water resources.

The concept of water use rights are given if the state is granted to the private sector too loosely. Philosophical construction that is adapted in the Water Law tends to place water as an economic commodity and this is often used as a basis for business actors as the basis for exploitation of water sources without regard to the rights of local communities to access and benefit of water resources that are controlled directly by the Company. As a result, the community around the water source has been deprived of its rights over water and other sources in the area.

Responding to this, various parties have sought to submit a judicial review of the water law at the Indonesian Constitutional Court. The first lawsuit filed in 2005 was rejected on the grounds that the Government of Indonesia entered into an WATSAL agreement with the International financial institution, the World Bank. The efforts of the new community succeeded after filing a lawsuit over the Water Law for the second time in 2013. On this occasion, the Constitutional Court granted the claim filed by PP Muhammadiyah. The Decree of the Constitutional Court No. 85 / PUU-XI / 2013 states that the Construction norm in the Constitutional Court Judge Council re-enacts Law Number 11 of 1974 concerning Irrigation and Government Regulation Number 22 of 1982 concerning Water Management.

The Constitutional Court Judges based its decision on the principle of Article 33 of the Constitution of the Republic of Indonesia which defines water as part of Public Goods, because 
the nature of water from the perspective of the constitutional economy is not an unlimited object; so that its use individually will reduce the availability of water to the general public On the one hand, the unique nature of water as a source of life on the other hand it is increasingly required to be seated as public property as opposed to private property, thus private control over water resources can be prevented by law. ${ }^{11}$

\section{Legal Implications of Water Privatization}

The MDG's led the GA to declare 2005-2012 as the International Decade for Action: Water for life in A/RES/58/217, adopted in December 2003. ${ }^{12}$ The Goal of the Water for Life Decade is to promote and facilitate efforts to fulfill international commitments made concerning water by $2015 .{ }^{13}$ It is action-oriented issues. An official World Water Day is held every march to discuss the progress of decade and durable solution regarding with this issue.

Several international agreements specifically address the issue of transnational waterways as they play a critical role in drinking water supply, agriculture, energy generations and industry. ${ }^{14}$ The 1992 UN Economic Commission for Europe (UNECE), Convention on the Protection and Use of Transboundary Watercourses and International Lakes (Water Conventions) was passed to strengthen management off and preservationist measures for international waterways. The 1997 UN Convention on the Non-Navigational Uses of International Watercourses" "equitable and reasonable use" and "the obligation not cause significant harm" to neighbors. This document leaves the definition of these principles up to individual nations and lacks specific enforcement and allocations mechanism. The UN has also knowledge the challenge water scarcity poses and in 1996 adopted the Convention on the Combat Desertification as densification further exacerbates scarcity and limits economic activity such as agriculture, industry and worker productivity. ${ }^{15}$

It is not easy to say who owns water. Law, in particular, as the formal instruments of orderly change in society, plays a pivotal role, wvwn though this role has not always been readily recognized. Other criticism has been raised water laws are irrelevant, inaccurate, outoff dated, rigid, mostly are not enforced and they exist only to consolidate the extreme positions of competing water user and highly charged adversarial claims, counter-productive to effective conflict resolution, in the arena of national water law, this may mean protected and expansive

\footnotetext{
${ }^{11}$ See Contitutional Court Decree Nomor 85/PUU-XI/2013 Regarding Revocation of Water Law

${ }^{12}$ United nations General Assembly, Resolution 58/217,2004

${ }^{13}$ Ibid

${ }^{14}$ International Decade for Action: Water for Life, 2005-2015, background: what a water for life decade

${ }^{15}$ United Nations Convention to Combat Desertification, about the Convention 2011
} 
litigation or administrative hearings. In transboundary (interstate) water law cases, the situation may be complicated by question of standing or jurisdiction, and litigation might also be lengthy and costly. At the internal level, in the absence of consent to dispute settlement procedures, the adversely affected instate may be subject to unilateral harmful acts of other sovereign states, without resource to quick effective remedies.

According to Rosemary Lyster Scientific Research conducted all water in the earth, only $2.35 \%$ is freshwater, the rest is sea water (saltwater). Of the $2.35 \%$ fresh water, two-thirds are trapped in glaciers and covered with permanent snow. The remaining one third is still littered with pollution. The data shows that there are around 2 million tons of fresh water wasted every day because of pollution and others. Meanwhile, in line with global climate change, water scarcity will increase by $20 \%$ in the next 25 years. ${ }^{16}$ On the other hand, the population continues to grow and the need for agricultural land to feed the earth's population is also increasing. ${ }^{17} \mathrm{In}$ line with the Rosemary Lyster Research, its research conducted by the International Water Management Institute (IWMI) also found that one third of the world's population is expected to experience severe water scarcity in the period up to 2025 , this condition has the potential to cause conflict and political crisis, and even war, especially in the Asia and Middle East region. ${ }^{18}$

Pros and Cons of the transfer of management rights of water resources from government power either partially or in whole into the hands of the private sector which is commonly called the privatization of water has become a matter of development which is quite debated during the past two decades. The derivative effect has occurred up to now, where every country competes with each other to privatize water. ${ }^{19}$ The liberalization and privatization agenda for water resources was first sponsored by International Financial Institutions (IMF and World Bank) after the 1992 Dublin Principal Declaration which campaigned on water management which contained the principles of water and environmental management policies consisting of: 1). Fresh water is a finite and vulnerable resource, essential to sustain life, development and the environment; 2). Water development and management should be based on a participatory approach, involving users, planners and policy-makers at all levels; 3). Women play a central

\footnotetext{
${ }^{16}$ Rosemary Lyster, "The Current Status of Water Law in New South Wales." (Makalah dalam seminar tentang Water Law Reform in New South Wales, the Faculty of Law, the University of Sydney, 22 September 2016)

${ }^{17}$ Ibid

${ }^{18}$ David Seckler, et.al., World water demand and supply, 1990 to 2025: Scenarios and issues. Research Report 19. (Colombo, Sri Lanka: International Water Management Institute, 1998), p. 7

19 . Surachman . 2019. Pengelolaan Sumber Daya Air Pasca Dibatalkannya UU No.7 Tahun 2004 Tentang Sumber Daya Air . Jurnal Living Law,Vol. 11, No.2,2019 p.98
} 
Administrative Law \& Governance Journal. Volume 2 Issue 1, March 2020 ISSN. 2621 - 2781 Online

part in the provision, management and safeguarding of water; 4). Water has an economic value in all its competing uses and should be recognized as an economic good

Armed with the four principles above, especially the first principle, namely the problem of water scarcity and the fourth principle concerning the problem of water scarcity and the fourth principle that qualifies water as an economic value object, International financial institutions make these two principles the basis in preparing resource policy proposals water globally. The transformation of the context of water into economic goods and the prediction of water scarcity in the future are used as a foothold by the World Bank and developed countries to make water into the economic framework of capitalism which emphasizes that the scarcer an object is, the higher its economic value. Since then, the capitalization of water resources has taken place massively with the support of International Financial Institutions and developed countries

Water and economic development are inextricability linked not only because of their relations through productivity but also because water is critical across many sectors, including agriculture, industry and services. Water is critical for development, because it is or has the potential to be, a critical source of energy, it facilitates the industrial process and it plays an important role in some transportation systems. A country's water management and development strategies and policies also effect development by affecting the demand for water, which interacts with supply to determine the level of water scarcity. Water scarcity physically affects 1.2 billion people worldwide and economically affects another 1.6 billion, as they do not have the infrastructure necessary to use what water resources are available. Water management is also critical to sustainable development because water facilitates survival, cleanliness, health, agriculture and food resources, industries and energy

Nowadays, Industrial management is a combination of public and private control. By the end of the 20th century, the practice of privatization was growing en masse. One factor is the request of the World Bank and the IMF to countries that are looking for funding to implement deregulation policies, be saved subsidy and sell water management assistance systems as well as infrastructure development in the private sector of the IMF and World Bank and beat the level of corruption. Investors will get the freedom and incentives to build, improve and upgrade for expensive water facilities. turn a profit. While governments in 
many of these countries do poor work in public financing (starvation often even occurs) the water industry. ${ }^{20}$

When the World Bank encourages privatization of water services throughout the world. The privatization action was carried out by companies based in the US and Europe. The privatization policy is accommodated through provisions in trade agreements and loan terms for developing countries. Privatization of services is the initial stage towards privatization of water resource management in a holistic manner. By means of globalization and privatization of water resources, there are indirectly efforts to replace collective ownership of water resources under the control of private companies. This step responded negatively with increasing opposition to water privatization. While the Supporters of privatization say that it has a track record of great success, increasing efficiency, quality, reliability and affordability of services to the population. ${ }^{21}$

The Transition of paradigm toward the function of water as an object of law which was once an ownerless object has now been turned into a business commodity that tends to lead to exploitation and privatization. Water privatization that encourages improvement in economic functions compared to social functions has the potential to cause conflicts of interest between sectors and regions and stakeholders who have an interest in water resources. The pattern of management of the water industry that emphasizes when the priority of commercialization interests tends to favor the owners of capital has the potential to neglect the essence of water as a social commodity that serves to meet the needs of the community at large.

A number of multinational companies that control water through the privatization route have a tendency to manage the water resources properly according to its function as a source of life. this is very contradictory to the campaign put forward by the World Bank on the privatization of water as a means / poverty alleviation strategy globally for developing countries. This is evidenced by the implementation of privatization requirements in eight poor countries that are World Bank debtors. The result is that many people are being sacrificed by high costs and high maintenance costs. In addition, private water companies

\footnotetext{
${ }^{20}$ Tri Inaya Zahra Conflict Between Indonesian Water Resources Law and 1945 Indonesian Constitution:Towards Water Privatization p.18

21 Van Overbeke, Dustin, Water Privatization [http://academic.evergreen.edu/g/grossmaz/VANOVEDR/ is accessed on 27 May 2020 pukul 23.00 WIB
} 
provide limited access to water, increase tariffs, and strengthen the unemployment rate by dumping public water sector jobs. ${ }^{22}$

Some of these companies even install prepaid water meters, where families buy prepaid cards with a certain amount of money. When money runs out, families are effectively cut off from water. ${ }^{23}$ Unwittingly, the policy of privatization in the management of water resources has produced huge consequences that must be borne by the weak economic community. Marginalization of economic rights of the weak economic community in gaining access to water needs is increasingly uncontrolled as a result of the swift flow of the practice of privatization of water management, even though water is the most basic need for every human being to be able to carry on his life that should be available / can be accessed freely and fairly by anyone. ${ }^{24}$

In addition, private companies make little effort to save water or protect ecological resources, because conservation does not turn a profit. ${ }^{25}$ In fact, several examples include many companies that violate operational standards and are involved in setting trade prices without calculating the consequences. This leads to conflicts over water issues with poor populations and creates a monopoly on water resources in the Area, which results in many people consuming water that has been contaminated and contains material that is harmful to health (although case studies show that privatized water can be highly contaminated too). ${ }^{26}$ This phenomenon implies that the water resources privatization program experienced many failures compared to the positive goals originally expected. The negative implications of privatization policy have a multi-sector impact, meaning that not only economically affects the community, but also ecological losses.

Some activists claim that the World Bank is only an instrument for corporate control over water. ${ }^{27}$ Reflecting on the negative implications of privatization, there are a number of points that need to be broadened. First, privatization is often assumed that private companies will prioritize meeting the needs of the communities around whom they serve. Of course this is not entirely appropriate, because it is very clear the Company's motives are motivated

Hughes, Richard A. 2014 . "Pro-Justice Ethics, Water Scarcity, Human Rights." Journal Of Law \&Religion 25.2 (2014): 521-540. Academic Search Complete. Web. 20 Nov.. P.526

${ }^{23}$ Hughes, Richard A. 2014 . Ibid

${ }^{24}$ Hamid Chalid, Arief Ainul Yaqin. 2018. Studi Tentang Hukum Air dan Problematika Pemenuhan Hak Atas Air di Indonesia . Jurnal Hukum dan Pembangunan 48 No. 2 (2018) . hal. 414

${ }^{25}$ Hughes, Richard A. 2014 . supra note p.535

${ }^{26}$ Tri Inaya Zahra Conflict Between Indonesian Water Resources Law and 1945 Indonesian Constitution:Towards Water Privatization supra note 20

27 Shiva, Vandana.2014 . Water Wars: Privatization, Pollution, and Profit. Cambridge, MA: South End Press, 2002. Print. Augustana College Library, 25 Nov. 2014.p.87 
by profits which allow it to be loyal when raising service tariffs, thus making poor citizens unable to buy water for their daily needs.).

In addition, privatization can lead to a reduction in the authority of government control in monitoring and acting as a commodity ruler. that everyone has access to water. When private companies take over, they often hold all the rights to water and its distribution, ${ }^{28}$ making local governments completely out of equality in the agreement. However, the government has the main task of ensuring that basic services, such as water, must be provided for the welfare of its people.

If the government does not play an active role in overseeing the management of the water sector, human rights to water can be threatened. Water privatization often has a negative impact on the environment. Water footprint in developed countries is very heavy and has the potential to damage ecosystems. Like the arguments and research descriptions described above, conservation does not produce profits, so private companies do not do much of the money,

Rarely are water source agreements concluded on considerations driven by primarily by legal, scientific and economic criteria related solely to the water resource. The situations is more complex, often involving cross-sectoral bargaining and unrelated trade-offs. Other policy issues such as national o global security, strategic interest, goals of environmental protection, good governance, poverty eradication, human rights and forth, may all influences decisions related to water resource development, but not necessarily be directly tied to it. The importance of these linkages must not have overlooked. This added layer of complexity highlight again the need for an open-ended approach to seeking an integrated solution to water related problems.

Water law continues to evolve. At the international level, increased transparency and more inclusive public participation and access to information and to transboundary remedies (i.e the principle of non-discrimination) have been introduced in recently adopted forwardlooking international agreement such as UNECE in 1998. Specific concerns related to health and aimed at limiting transboundary impact such as recognizing the notion that "prevention pays off", are also found in watercourse convention. Current inactive is such as the proposed European Union Water Framework Directive and the project sponsored by UN Economic Commission for Europe and UN Environmental Programs (UNECE/UNEP) on monitoring

${ }^{28}$ Gleick, Peter H., et al. 2014 . "The New Economy of Water: The Risks and Ben efits of Globalizationand Privatization of Fresh Water." Pacific Institute. http://pacinst.org/publication/neweconomy-of-water/. Web. Accesed on 28 May 2020 
compliance and public participation demonstrate the evolutive character and responsive nature of legal instruments aimed at water resources management. In other words, current solution for water problems around the world involving upstream and downstream contest at the national and international level demonstrate the success of integrated interdisciplinary designed response.

\section{Case Stud : PT. Tirta Investama (Aqua Danone) vs Padarincang Society}

One of the cases that led to the legal consequences of friction between community rights over water sources with private investment is the case between PT. Tirta Investama with the Padarincang community, Kab. Serang in 2008. This case originated from the factory construction plan that will be carried out by the company producing bottled water (PT. Tirta Investama), which was rejected by villagers domiciled around the water source. So that the plan was postponed. However, in 2010, the Company approached the Regional Government namely the Serang Regent and the Governor of Banten Province until it was permitted to carry out operational activities. The way to approach the company is to invite the Regent and Governor to visit the Danone Headquarters in France.

This was responded by the Padarincang Community where as many as ten thousand local villagers held a demonstration to the Regional Government of Serang Regency over a plan that had the opportunity to provide an opportunity for the company to extract groundwater resources which potentially posed a threat to subsistence farming in the surrounding population. The reason for the rejection of Padarincang residents is based on the belief that water is the source of human life, so it is not allowed to be exploited as a business commodity. The threat of drought is also used as the basis for the rejection of the Padarincang people. Natural events such as the geological process of replenishing hydro, drainage and groundwater disposal are not subject to disruption. Excessive exploitation of groundwater together with the use of agricultural land irrigation will lead to land subsidence and land subsidence in underground water basins which can lead to ecological disasters.

The standardization on Production that carried out by the Company is emphasized on the number of market demand without regard to the condition of the natural ability of the production environment. underground water of the region. This action poses a big long-term risk which causes a deficit in the availability and quality of surface water which can lead to a water crisis. Nevertheless, the Local Blood Government still provides support for operational permits for PT. Tirta Investama. The sporadic Padarincang community protection by burning down the water distillation factory caused the operational 
Administrative Law \& Governance Journal. Volume 2 Issue 1, March 2020 ISSN. 2621 - 2781 Online

sustainability of PT. Tirta Investama was canceled by the local government for security reasons.

\section{Evaluation Toward Policy on Water Resource Management}

\subsection{Best Practice Harmonizing Privatization and People's Right on Water Access}

The events that occurred between the Padarincang community and PT. Tirta Investama is a social conflict that often occurs in the community over a business activity that is in contact with aspects of the lives of the surrounding population. Those who support the plan to build a water resource management plant are based on the excrement of employment opportunities, while those who are cons are making environmental reasons and violating the local Daeah Government law, due to the lack of a socialization process to gain public legitimacy from local local residents.

Operating licenses for businesses that intersect with the environment of resource exploitation Permits can only be issued if an Environmental Impact Assessment or Environmental Impact Analysis Report has been issued by the competent authority. Based on the Regulation of the Minister of Environment of the Republic of Indonesia Number 5 of 2012 Concerning Types of Business Plans and / or Activities Required for Environmental Impact Assessment, mentioned in Appendix I, that groundwater extraction efforts require AMDAL. Meanwhile the lobbying action carried out by PT. Tirta Investama to the local Regional Government without regard to the AMDAL instrument is not justified according to the regulation. This basis was made the legal basis for the residents of Padarincang asking their Regent to revoke the Permit immediately (License number 593 / Kep.50-Huk / 2007 dated February 8, 2007

Reflecting on the above case, the Government should pay attention that economic development based on the investment axis must also respect the rights of citizens around. Harmonizing the balance of rights between business actors and the community is a component that must be understood in order to create sustainable and beneficial economic development for both sides. Parties, paying attention to the case description above, Indonesia must learn from other countries in synchronizing the fulfillment of the needs of community rights with the role of private companies.

The principle that must be considered is that the laws and implementing regulations must be aimed at increasing the access of the poor to clean water. As John Rawls said in his "A Theory of Justice", the making of regulations must be built to maximize the privileges 
of the most disadvantaged members of society, or as Mohammad Hatta said, to protect the weak from exploitation by those who have capital. ${ }^{29}$

One of the developing countries that has successfully implemented the management of the privatization of water resources by fulfilling the people's right to water in harmony is Chile. The Chilean government issued a privatization policy on water management in the form of a concession in 1998 under the leadership of President Eduardo Frei's democratic government until 2006 by the President of Lagos. Privatization was carried out by selling the shares of three companies operating in the Santiago, Valparaiso and Concepcion regions. ${ }^{30}$ This was followed up by the Chilean government adopting Law 19549 into a law that significantly changed the legal framework for clean water and sewage systems in Chile.

The application of this regulation is the basis for the transfer of ownership of water companies and public disposal systems to the private sector. Until 2004, all public water companies were privatized, both in the form of selling shares and forming concessions with foreign companies. However, in 2001, the Government of Chile discontinued privatization using the method of selling shares and decided to transfer the exploitation rights of public companies to the private sector. This happened to the EMOS corporation that got the unlimited duration of the concession given to the IAM private consortium. ${ }^{31}$ In the concession formed, the private consortium is committed to managing and developing a water management and waste management system in the urban area of Santiago as well as creating a number of investment values that are prioritized in the field of waste treatment

The concession system places the private sector in managing the company's assets, operating company activities, and investing in the maintenance and expansion of the company's system. This model encourages concession periods to be longer than forms of privatization, because the private sector is given the task of creating performance efficiencies and expanding the business connection system. The selection of the concession model is intended to keep public assets under state control, without the need to transfer rights of acquisition. to the private sector.

The role of regulatory institutions has become an important key in privatization, because with the support of regulators, business efficiency can be achieved. In the

\footnotetext{
${ }^{29}$ Al'Afghani, Mohamad Mova, Supranote. 14, p. 18

${ }^{30}$ Bitrán, Gabriel dan Eduardo Valenzuela. 2003. "Water Services in Chile: Comparing Private and Public Performance." Public Policy for the Private Sector, no. 255 inside Tara Farahdiba. 2016 . Keberhasilan Privatisasi Pengelolaan Air Bersih . Jurnal Analisis Hubungan Internasional Vol 5 No. 2 Juni 2016

${ }^{31}$ Hall, David dan Emanuele Lobina. 2004. "Private and Public Interests in Water and Energy." Natural Resource Forum, vol. 28 issue 4.
} 
nomenclature of the Chilean state, SISS's position is a regulatory body under the Ministry of Public Works. The establishment of SISS as supervisor of private companies managing water and waste is based on Chilean Law No. 18902 which was ratified on January 27, 1990. Through SISS, a new regulation was also made under a new law related to water and sanitation management contained in Ley General de Servicios Sanitario, DFL 382. SIIS also has a role to take preventive measures against consumer exploitation might occur in the process of privatization.

However, privatization in the service sector also had a negative effect, namely a rise in service tariffs as a consequence of investment made by companies to improve services to the public. The service rates that apply in Chile can be said to be quite high. Noted in December 2007, the tariff on consumption of the first 20 cubic meters was 11.199 Chilean pesos, equivalent to US $\$ 19.83 .{ }^{32}$ Although service tariffs continue to increase every year, their implementation is determined by taking into account the affordability limits that are acceptable to the community. Based on the Chilean National Statistics Institute, the average monthly income owned by the community in the Santiago area is 713,926 Chilean pesos, equivalent to US $\$ 1,264.64$. This means that the average cost incurred by each household to meet the need for water is $1.56 \%$ of the total monthly income

The affordability of the Chilean community is also influenced by the growing national economic Chile. Cross subsidies are provided by the Chilean government to enable poor residents to continue to receive services and meet clean water needs.

\subsection{The Legal Strategy for Indonesian Government In order to Design Legal Political on National Water law}

Based on Article 33 of the 1945 Constitution of the Republic of Indonesia Decision of the Constitutional Court Number 85 / PUU-. XI / 2013, the reconstruction of the National Water Law, The position of the state plays a vital role in the control of water resources through State Owned Enterprises and Regional-Owned Enterprises. The granting of a monopoly on control is aimed at ensuring the fulfillment of human rights for citizens, namely the right to water resources. Private Parties are still given portions and permits to participate in managing water sources, but with strict provisions.

\footnotetext{
${ }^{32}$ Baer, Madeline. 2014. "Private Water, Public Good: Water Privatization and State Capacity in Chile." Studies Comparative International Development
} 
Post-Revocation of Law No. 7 of 2004 concerning Water Resources through the Decision of the Constitutional Court of the Republic of Indonesia, the legal instrument used as the basis for the management of water resources is to return to Law Number 11 of 1974 concerning Irrigation. The decision must be implemented because it is final and binding as part of checks and balances in the field of legislation. Water management policies as contained in Law No. 11 of 1974 must be implemented. ${ }^{33}$ In the management of water operations, Law No. 11 of 1974 the irrigation system regulates the right to manage water resources carried out by the central government and can be delegated to local governments.

If there is any private party interested in managing and managing water, it needs to be done with a joint effort with the principle of kinship (cooperative). Therefore, in line with the spirit of returning the role of government in accordance with Law No. 11 of 1974, the local government and the community around the spring. So far, the management carried out by the government or local government in water management can be done by PDAM, but this water management model cannot directly touch the social function of water, although this model is allowed in law. The social function of water is not optimal because the community does not have more access to the presence of the PDAM.

Ratification of Law Number 6 of 2014 concerning Villages, provides access to village autonomy in preparing budgets for the welfare of village communities. One of the new institutional instruments set out in the Act is the Village-Owned Enterprise. The concept is almost the same as Regional-Owned Enterprises. The only difference is that the BUMD manages the local government and there is no involvement of the general public, especially in making strategic decisions, but the existence of the Village-Owned Enterprises is formed by the village community, based on consultation and agreement of the local village community.

The involvement of the Village-Owned Enterprises is very suitable for the water management business. Springs that are located on village land or government-owned land can be used as objects of. Village-Owned Enterprises Through water management by, VillageOwned Enterprises automatically carrying out social functions from water will be maximized, Village-Owned Enterprises besides running economic functions as a source of income, Village community supervision can directly oversee water management in the area concerned. Water managed by the Village-Owned Enterprises can be channeled to inns, public toilets and other businesses that need water, in addition to the household consumption of villagers.

\footnotetext{
33 Aan Eko Widiarto, "Ketidakpastian Hukum Kewenangan Lembaga Pembentuk Undang-Undang Akibat Pengabaian Putusan Mahkamah Konstitusi”, Jurnal Konstitusi, Volume 12, Nomor 4, Desember 2015, h.747
} 


\section{Conclussion}

A major chalenge facing both developed countries and developing countries is how to supply safe drinking water to their citizenship. The demand for the water is rising at an expotential rate due to increasing population and pollution of water sources. Many factors are reported to be responsible for the inadequate and inquitable water distribution of improved water in countries involved with this issue

Revocation of the Water Resources Law as a legal instrument that regulates water management makes Indonesia currently does not have an up-to-date legal umbrella, in order to bridge the legal vacuum over this crucial issue. The return of the function of the Irrigation Law as a legal umbrella to deal with water source problems, in my opinion, cannot be used comprehensively. Because the irrigation aspect only covers a small part of the use of more complex water resources. So that the Government of the Republic of Indonesia needs to immediately draft a new law in the field of water resources that is able to balance the interests of the community and private business actors proportionally. The regulation of water resources exploration permits must emphasize the fulfillment of people's rights, bearing in mind that the right to access water is part of human rights. Water resources exploitation is also required to pay attention to ecological aspects for sustainable development

Water scarcity that is often questioned in global campaigns, in the national perspective is not due to the lack of water sources, but rather emphasizes the revitalization of infrastructure and its management that must be addressed. Before drafting a draft law on water resources, it would be better for the government to understand the upstream to downstream cycle, the management of water management recycling and its designation in community activities.

Understanding of these matters is important to emphasize because if when drafting regulations these things are not examined then it is feared that regulations will be counterproductive and threatened with being sued by the community. Inventory of spring and spring information system availability. the preparation of the mapping regarding which areas have potential water sources needs to be immediately executed by the Government. Synergy or continuity between the central and regional bureaucracy needs to be improved. The involvement of Village - Owned Enterprises role as an agent of economic development in the region by using local wisdom-based management and utilization as a philosophical basis needs to be considered. 


\section{Bibliography}

Aan Eko Widiarto, "Ketidakpastian Hukum Kewenangan Lembaga Pembentuk UndangUndang Akibat Pengabaian Putusan Mahkamah Konstitusi”, Jurnal Konstitusi, Volume 12, Nomor 4, Desember 2015

Abubakar, MAK., 2006. Water Supply and sanitation sector reform initiatives in Nigeria Proceeding of the 29th WEDC Conference, Symposium on a Key National Issue, Sep 24 Nigeria, 1996

Ahmad Redi. 2014.Hukum Sumber Daya ALam dalam Sektor Kehutanan. Jakarta Timur:Sinar Grafika

Al'Afghani, Mohamad Mova, Anti privatization Debate, Opaque Rules and Neglected 'Privatized' Water Services Provision: Some Lessons from Indonesia, Background Paper STEPS II Conference, "Liquid Dynamics", organized by the International Development Study (IDS) at the University of Sussex, Sussex, 22-23 March 2011, p. 3. p. 3.

Baer, Madeline. 2014."Private Water, Public Good: Water Privatization and State Capacity in Chile." Studies Comparative International Development

Basah Hernowo, Kebijakan Nasional Pengelolaan Sumber Daya Air, Direktorat Kehutanan dan Konservasi Sumber Daya Air, Kementrian PPN/BAPPENAS yang diakses pada https://www.bappenas.go.id/id/berita-dan-siaran-pers/keterpaduan-konservasisumber-daya-air-kunci-pembangunan-berkelanjutan/accesed on May 272020 at 11.30 PM

Bitrán, Gabriel dan Eduardo Valenzuela. 2003. "Water Services in Chile: Comparing Private and Public Performance." Public Policy for the Private Sector, no. 255 inside Tara Farahdiba. 2016 . Keberhasilan Privatisasi Pengelolaan Air Bersih . Jurnal Analisis Hubungan Internasional Vol 5 No. 2 Juni 2016

Caflisch, L. "the Law of International Waterways and Its Sources." In R. St.J Macdonald, ed. Essay in Honor of Wang Tieya, Nijoff, 1993.

Constitution of The Republic of Indonesia

Contitutional Court Decree Nomor 85/PUU-XI/2013 Regarding Revocation of Water Law

Dave and Nalco, Susitanable Development Role of Industrial Water Management, 2004.

David Seckler, et.al., World water demand and supply, 1990 to 2025: Scenarios and issues. Research Report 19. (Colombo, Sri Lanka: International Water Management Institute, 1998)

Fisher and Hubber-Lee, Economi, Water Management and Conflict Resolution in the Middle East and Beyond, 2006

Food and Agricultural Organization of the United Nations, Syirian Arab Republic, 2008

Food and Agriculture Organization of the United Nations, The Wealth of Waste: The Economic of Wastewater Use in Agriculture, 2010 
Gleick, Peter H., et al. 2014. "The New Economy of Water: The Risks and Ben efits of Globalizationand Privatization of Fresh Water." Pacific Institute. http://pacinst.org/publication/neweconomy-of-water/. Web. Accesed on 28 May 2020

Hall, David dan Emanuele Lobina. 2004.” Private and Public Interests in Water and Energy.” Natural Resource Forum, vol. 28 issue 4

Hamid Chalid, Arief Ainul Yaqin. 2018. Studi Tentang Hukum Air dan Problematika Pemenuhan Hak Atas Air di Indonesia. Jurnal Hukum dan Pembangunan 48 No. 2 (2018)

Helmi Kasim dan Titis Anindyajati, "Perspektif Konstitusional Kedudukan Negara dan Swasta dalam Pengelolaan Sumber Daya Air Menurut UUD 1945," Jurnal Konstitusi, Volume 13, Nomor 2, (Juni, 2016)

Hildering, International law Sustainable Development and Water Management, 2004.

Hughes, Richard A. 2014. "Pro-Justice Ethics, Water Scarcity, Human Rights." Journal of Law \&Religion 25.2 (2014): 521-540. Academic Search Complete. Web.

International Decade for Action: Water for Life, 2005-2015, background: what a water for life decade

Kherici, Mobilization and Management of the Water Resources in the North-East Algeria, 2009

Law No.7/ 2004 regarding Water Resources

Lorenz, Strategic Water for Iraq: The Need for Planning and Action, 2008

Rosemary Lyster, "The Current Status of Water Law in New South Wales." (Makalah dalam seminar tentang Water Law Reform in New South Wales, the Faculty of Law, the University of Sydney, 22 September 2016

Russel et al. Economic Instruments for Water Management in the Middle East and North Africa, 2007

Shiva, Vandana.2014. Water Wars: Privatization, Pollution, and Profit. Cambridge, MA: South End Press, 2002. Print. Augustana College Library, 25 Nov. 2014.

Surachman . 2019. Pengelolaan Sumber Daya Air Pasca Dibatalkannya UU No.7 Tahun 2004 Tentang Sumber Daya Air. Jurnal Living Law,Vol. 11, No.2,2019

Tri Inaya Zahra Conflict Between Indonesian Water Resources Law and 1945 Indonesian Constitution:Towards Water Privatization

UNEP (2004) Understanding Environemne, Conflict and Cooperation, United Nations Convention to Combat Dessertification, about the Convention 2011

United Nations Departements of Economic and social Affairs, Population Division, 2004.

United nations General Assembly, Note by the Secretariat on Water and the International Aggreed Development Goals (A/64/694), 2011

United nations General Assembly, Resolution 58/217,2004

United Nations University, Welcome to the UN-Water Decade Program on Capacity Development

Van Overbeke, Dustin, Water Privatization Conflicts. [http://academic.evergreen.edu/g/grossmaz/VANOVEDR/ is accessed on 27 May 20 
Administrative Law \& Governance Journal. Volume 2 Issue 1, March 2020 ISSN. 2621 - 2781 Online

Varis, Right to Water: The Millineum development Goals abd Water in the MENA region, 2007

World bank, Making the Most of Scarcity: Accountability for Better Water Management in the Middle East and North Africa, 2007

World Bank: Making the Most of Scarcity: Accountability for Better Water Management in the Middle Earth and North Sfrica, 2007

World Health Organization and United Nations Childern Fund WHO/UNICEF joint monotoring (JMP) for Water Supply and Sanitation 